JURNAL ILMIAH KOMPUTERISASI AKUNTANSI, Vol. 13, No. 1, Juli 2020, pp. 75 - 87

p-ISSN : 1979-116X (print)

e-ISSN : 2614-8870 (online)

http://journal.stekom.ac.id/index.php/kompak

\title{
APLIKASI WEBSITE SISTEM INFORMASI AKUNTANSI MANAJEMEN KEUANGAN TALANG GANTUNG ADVENTURE
}

\author{
Sukemi Kamto Sudibyo ${ }^{1}$, Wahyu Ariyani ${ }^{2}$ \\ ${ }^{1}$ Komputerisasi Akuntansi STEKOM, Semarang, e-mail: sukemi@ stekom.ac.id \\ ${ }^{2}$ Komputerisasi Akuntansi STEKOM, Semarang, e-mail: wahyuariyani1995@gmail.com
}

\section{ARTICLE INFO}

Article history:

Received 30 Mei 2020

Received in revised form 15 Juni 2020

Accepted 10 Juli 2020

Available online 12 Juli 2020

\begin{abstract}
Talang Gantung Adventure is engaged in learning services outside the classroom or open air which is usually called outbound. In carrying out operational activities there are always financial transactions. However, in Talang Gantung Adventure, financial management still uses manual recording, which is recording in a ledger. Financial reports to the owner of the Talang Hang Adventure are performed using Microsoft Excel. Manual Financial Management results in vulnerability in storing financial data and is difficult to find data so that it has not been effective and has difficulties in preparing financial reports.

Based on this research the authors designed and made a financial management accounting information system website application Talang Gantung Adventure. The purpose of making this system is to facilitate the recording of financial transactions, facilitate the search for data and be safer in storing Talang Gantung Adventure data storage, and to produce financial reports that are easily reported to the owner of Talang Gantung Adventure wherever and whenever.
\end{abstract}

Keywords: Application, Information System, Accounting, Finance, Website

\section{Pendahuluan}

Seiring dengan perkembangan perekonomian yang semakin pesat tidak dapat dipisahkan oleh perkembangan teknologi, terutama teknologi informasi komputerisasi. Untuk menghasilkan informasi yang cepat, tepat dan akurat setiap perusahaan atau instansi baik pemerintah maupun swasta dituntut dapat menyesuaikan perkembangan teknologi tersebut. Dengan persaingan bisnis yang ketat, setiap perusahaan selalu berusaha untuk selalu unggul dalam menghasilkan sebuah produk atau memberikan pelayanan yang terbaik kepada pelanggan. Adanya teknologi informasi di bidang akuntansi dapat mempermudah dalam memanajemen keuangan dan menghasilkan laporan keuangan.

Dalam menjalankan segala aktivitas untuk mencapai suatu tujuan, maka dibutuhkan adanya kas, misalnya untuk pembelian barang, pembayaran listrik, telepon dan lain-lain. Dengan kata lain, kas berperan sebagai media pertukaran yang terlibat langsung maupun tidak langsung

Received Mei 23, 2020; Revised Juni 29, 2020; Accepted Juli 12, 2020 
pada sebagian besar transaksi pada Talang Gantung Adventure. Talang Gantung Adventure yang berlokasi di Dukuh Kampung Baru, Desa Sidomukti, Weleri bergerak di bidang jasa outbound yang didirikan oleh Bapak Yusuf Efendi sejak tahun 2015. Talang Gantung Adventure ini menyediakan berbagai macam area untuk outbound. Dalam pelaksanaan kegiatan operasionalnya selalu ada transaksi keuangan. Namun pada Talang Gantung Adventure manajemen keuangan masih menggunakan pencatatan manual, yaitu pencatatan masih dalam buku besar. Laporan keuangan ke pemilik perusahaan dilakukan dengan menggunakan sistem Microsoft Excel. Penelitian ini bertujuan untuk mengetahui efektifitas manajemen keuangan pada Talang Gantung Adventure. Pengelolaan keuangan pada Talang Gantung Adventure yang masih menggunakan manual mengakibatkan kerawanan penyimpanan datanya serta sulit dalam pencarian datanya sehingga belum efektif dan lebih mudah dalam pembuatan laporan keuangan. Oleh sebab itu, Talang Gantung Adventure membutuhkan sebuah aplikasi manajemen keuangan.

Metode yang digunakan sebagai pendekatan dalam perancangan sistem informasi akuntansi manajemen keuangan di Talang Gantung Adventure adalah dengan menggunakan metode accrual basis. Penggunaan metode accrual basis didasarkan atas sistem pencatatan transaksi yang dilakukan oleh Talang Gantung Adventure tersebut.

Dari latar belakang diatas, aplikasi website sistem informasi akuntansi manajemen keuangan Talang Gantung Adventure yang akan digunakan peneliti adalah PHP dengan database $M y S q l$. Penggunaan database $M y S q l$ untuk penyimpanan data agar lebih aman dan dalam pencarian data akan lebih mudah dibanding dengan menggunakan sistem lama.

\section{Tinjauan Literatur}

\section{a. Sistem}

Sistem adalah kumpulan elemen yang saling berkaitan dan bekerja sama dalam melakukan kegiatan untuk mencapai suatu tujuan. (1)

b. Informasi

Informasi merupakan data yang sudah diolah yang ditujukan untuk seseorang, organisasi ataupun siapa saja yang membutuhkan informasi tersebut. (2)

\section{c. Akuntansi}

Akuntansi adalah proses dari transaksi yang dibuktikan dengan faktur, lalu dari transaksi dibuat jurnal, buku besar, neraca lajur, kemudian akan menghasilkan informasi dalam bentuk laporan keuangan yang digunakan pihak-pihak tertentu. (1)

d. Sistem Informasi Akuntansi

Sistem informasi akuntansi merupakan sekelompok struktur dalam sebuah entitas yang mengelola sumber daya fisik dan sumber daya lain untuk mengubah data ekonomi menjadi informasi akuntansi, agar dapat memenuhi kebutuhan informasi berbagai pihak. (3)

e. Manajemen keuangan

Manajemen keuangan merupakan suatu bidang pengetahuan yang cukup menyenangkan sekaligus menantang karena pihak yang senang dalam bidang manajemen keuangan akan mendapatkan kesempatan yang lebih luas untuk memperoleh pekerjaan seperti coporate finance managers, perbankan, real estate, perusahaan asuransi, bahkan sektor pemerintahan yang lain, sehingga karier akan berkembang.(4)

Penerimaan kas perusahaan biasanya yang reguler berasal dari dua sumber utama, yaitu: penerimaan kas berasal dari penjualan tunai dan dari piutang atau pembayaran dari penjualan kredit. Pengeluaran kas berupa pembayaran bisa menggunakan uang tunai maupun cek. (1) 
Akuntansi berbasis akrual (Accrual Basis) merupakan sistem akuntansi yang mencatat dan mengakui suatu transaksi usaha pada saat terjadinya transaksi. Jika dalam kegiatan usaha menghasilkan suatu pendapatan jasa atau penjualan barang akan langsung diakui sebagai pendapatan pada saat terjadinya transaksi tanpa memperhatikan apakah kas sudah diterima atau belum, dan demikian juga dengan beban yang timbul akan diakui dan dicatat dalam buku pada saat terjadinya transaksi tanpa memperhatikan apakah sudah dikeluarkan atau belum. (5)

\section{Metode Pengembangan \\ Metode Penelitian}

Metode penelitian yang dilakukan dalam penelitian ini adalah menggunakan metode penelitian pengembangan (R\&D) atau yang disebut pengembangan berbasis penelitian yaitu proses yang digunakan untuk mengembangkan dan menguji keefektifan produk. Mengambil dari metode R\&D yang dikembangkan (6), dalam penelitian ini penulis menggunakan enam langkah tahapan penelitian, yaitu:

\section{Potensi dan masalah.}

Masalah yang dihadapi oleh Talang Gantung Adventure adalah manajemen keuangan masih menggunakan pencatatan manual, yaitu pencatatan masih dalam buku besar. Laporan keuangan ke pemilik Talang Gantung Adventure dilakukan dengan menggunakan Microsoft Excel. Manajemen keuangan secara manual mengakibatkan kerawanan penyimpanan data keuangan serta sulit dalam pencarian datanya sehingga belum efektif dan berakibat kesulitan dalam pembuatan laporan keuangan.

\section{Pengumpulan data.}

a. Metode Wawancara. Peneliti mengajukan pertanyaan kepada pemilik Talang Gantung Adventure berkaitan dengan sistem informasi yang sedang berjalan.

b. Metode Observasi. Dalam metode ini peneliti melakukan studi lapangan di objek penelitian yaitu Talang Gantung Adventure di Dukuh Kampung Baru RT 02/VI, Desa Sidomukti, Kecamatan Weleri, Kabupaten Kendal, Jawa Tengah.

c. Metode Studi Pustaka. Mempelajari buku-buku yang dapat menunjang penelitian yang didapat dari berbagai sumber yang berhubungan dengan pengembangan sistem.

3. Desain produk. Pada tahapan ini software yang digunakan yaitu PHP dan MySql sebagai databasenya menggunakan metode Accrual Basis.

4. Validasi desain. Setelah desain produk selesai dibuat, maka dilakukan evaluasi yang dilakukan oleh pemilik Talang Gantung Adventure. Tahap ini ditunjukan untuk menilai kesesuaian desain produk dengan tujuan penelitian dan bila ada kekurangan dan kesalahan, maka harus dilakukan perbaikan.

5. Revisi desain. Melakukan perbaikan terhadap kekurangan dan kelemahan sistem yang ada, serta menambah komponen-komponen dari masukan-masukan evaluasi, untuk menyempurnakan produk yang kemudian diujikan kembali kepada pihak Talang Gantung Adventure .

6. Uji coba produk. Pada tahap ini dilakukan uji coba terhadap model beserta instrumen dan perangkat modelnya yang bertujuan untuk mengetahui sejauh mana model evaluasi beserta instrumen dan perangkat model tersebut dapat diterapkan di Talang Gantung Adventure. Data dari hasil uji coba kemudian dianalisis untuk mengetahui apakah model tersebut sudah layak digunakan atau belum. Apabila model evaluasi beserta instrumen ternyata belum memenuhi persyaratan fit model kemudian direvisi dan diujicobakan kembali. 
Model Pengembangan Sistem

Model pengembangan sistem yang akan digunakan adalah model prototype, model prototype memberikan sebuah gambaran tentang cara kerja yang akan berfungsi dalam bentuk sederhana. Tahapan-tahapan dalam pengembangan prototype :

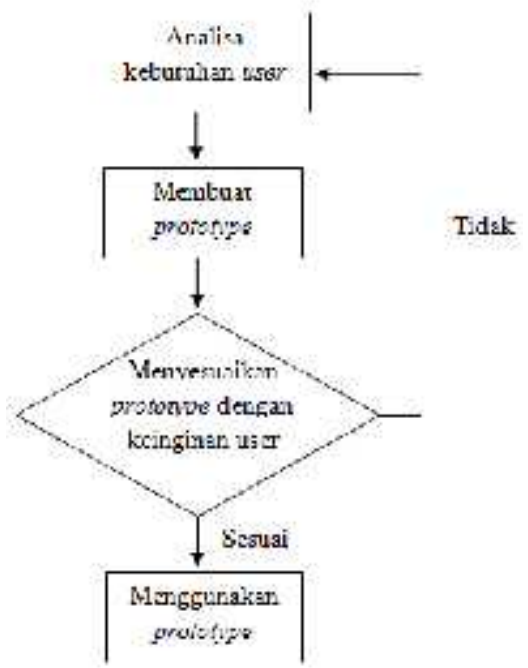

Gambar 1 Model Proses Prototyping (2)

\section{Hasil Penelitian}

Hasil Pengembangan

Didalam aplikasi website sistem informasi akuntansi manajemen keuangan Talang Gantung Adventure ini terdapat 3 hak askses yaitu kasir, administrasi dan pemilik yang diberikan hak akses sebagai administrator.

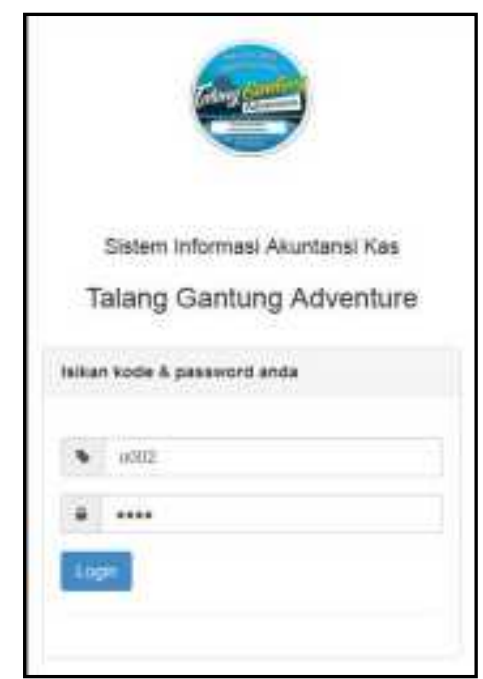

Gambar 2 Halaman Login Pengguna

JURNAL ILMIAH KOMPUTERISASI AKUNTANSI Vol. 13, No. 1, Juli $2020: 75-87$ 
Untuk masuk ke sistem, pengguna harus login terlebih dahulu dengan input kode dan password yang benar. Selanjutnya pengguna akan masuk ke aplikasi yang terdiri dari menu Home, Master Data, Transaksi dan Laporan. Didalam menu Master Data terdiri dari sub menu data pengguna, rekening dan paket, untuk Menu Transaksi terdiri dari sub menu booking, pelunasan, kas masuk dan kas keluar. Untuk Menu Laporan terdiri dari sub menu laporan piutang, laporan pelunasan, laporan kas masuk, laporan kas keluar, laporan arua kas dan laporan laba rugi serta laporan pajak.

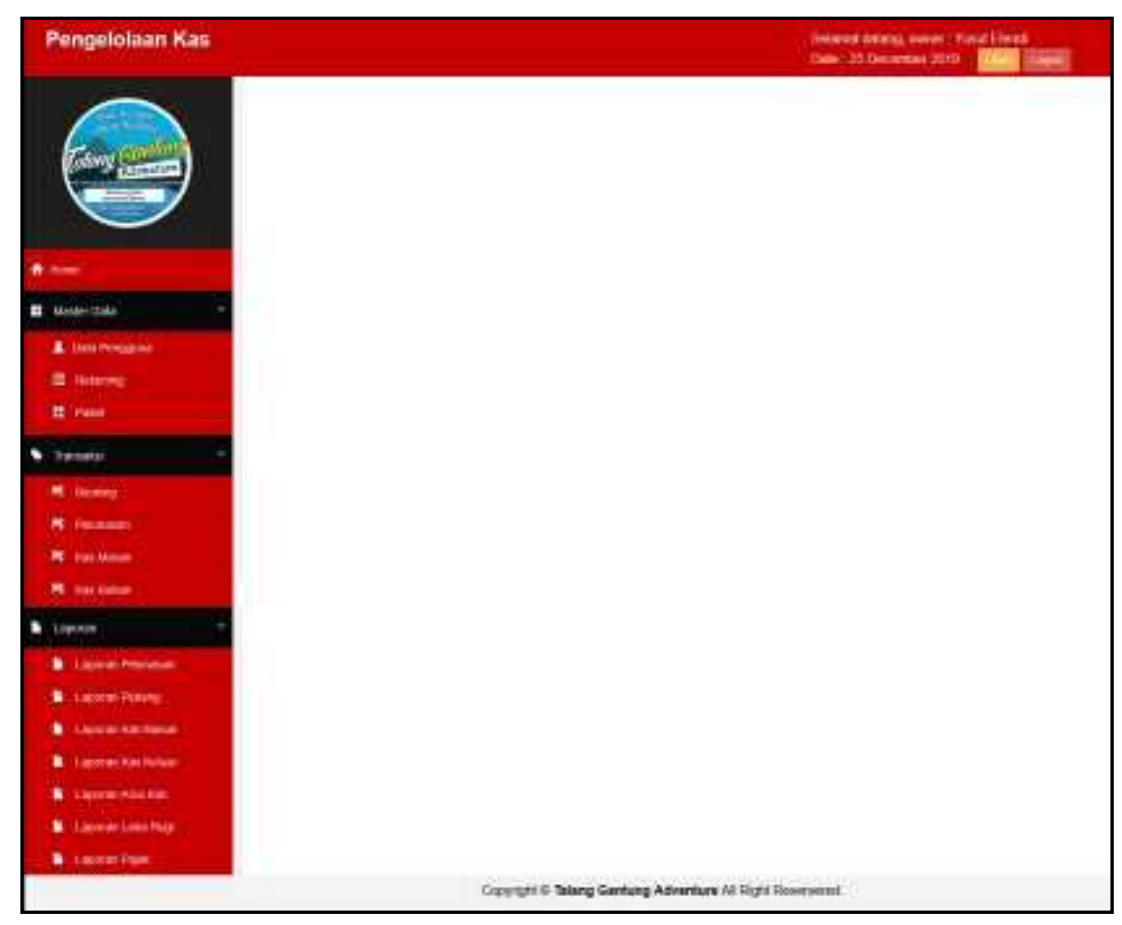

Gambar 3 Halaman Utama Pengguna

Menu Home menampilkan halaman awal pengguna setelah berhasil login

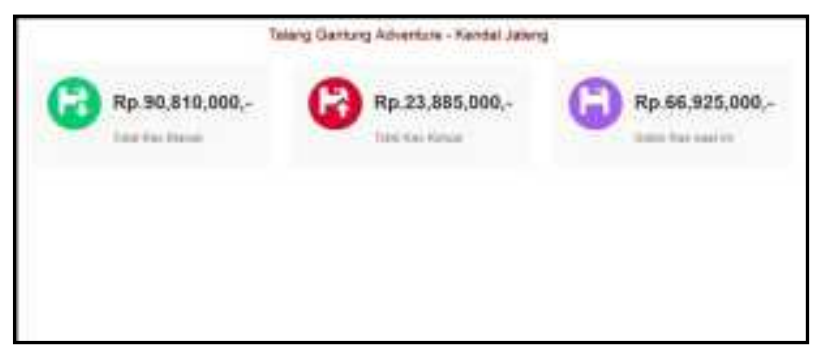

Gambar 4 Halaman Home

Sub menu data pengguna dapat digunakan Pemilik untuk mengelola data pengguna. Pemilik dapat menambah, mengubah, menghapus data pengguna. 


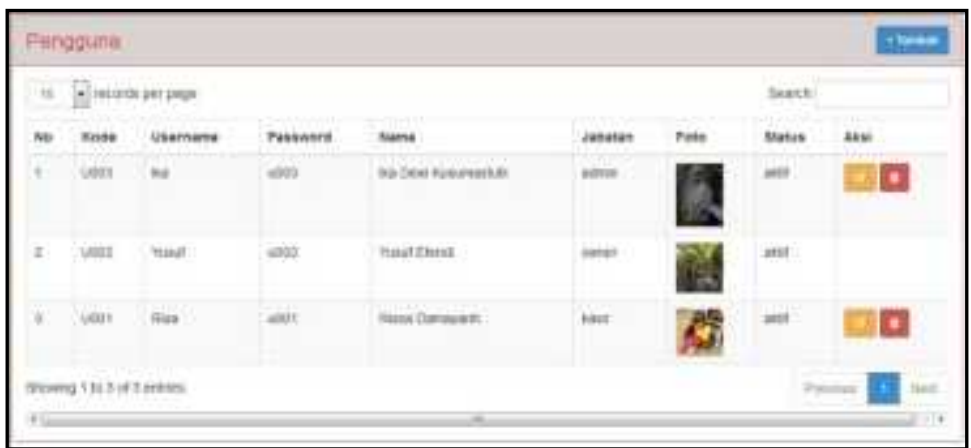

Gambar 5 Halaman Data Pengguna

Sub menu rekening digunakan untuk mengelola rekening bagi data kas masuk dan kas keluar. Pengguna dapat menambah, mengubah, menghapus rekening.

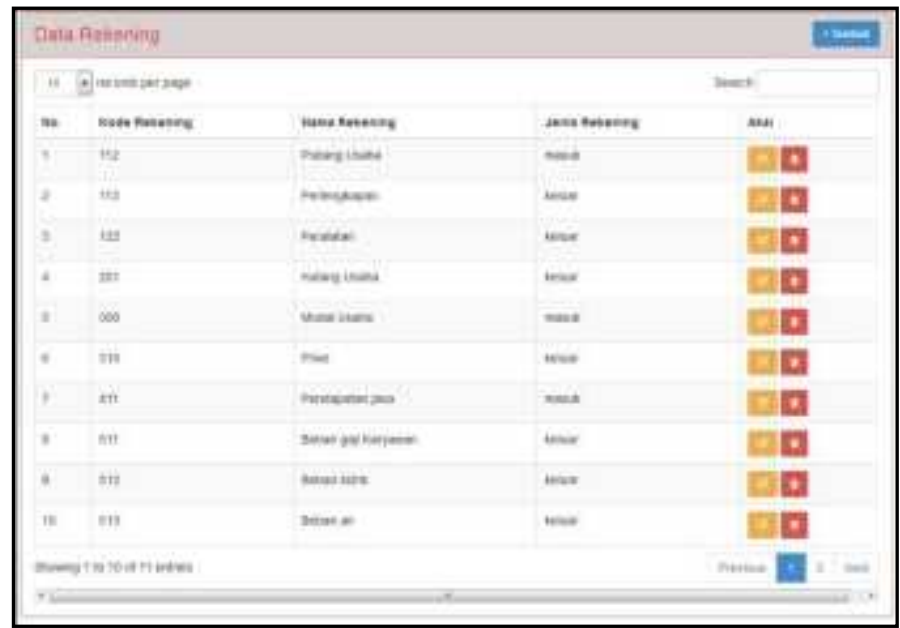

Gambar 6 Halaman Rekening

Sub menu paket digunakan untuk mengelola paket outbound. Pengguna dapat menambah, mengubah, menghapus paket.

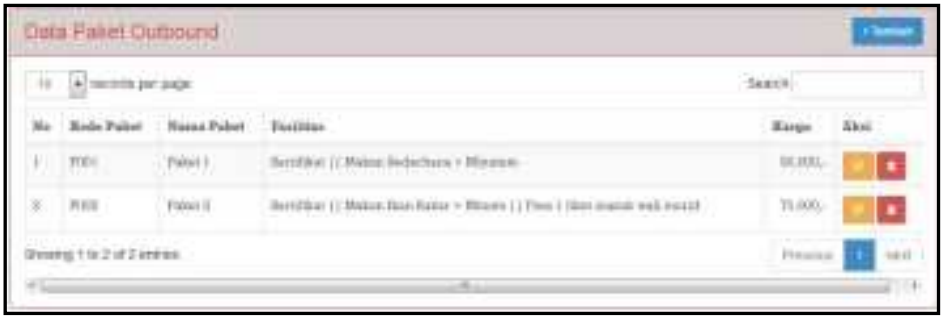

Gambar 7 Halaman Paket

Sub menu kas masuk digunakan untuk mengelola data kas masuk selain dari pendapatan jasa. Pengguna dapat menambah, mengubah, menghapus data kas masuk.

JURNAL ILMIAH KOMPUTERISASI AKUNTANSI Vol. 13, No. 1, Juli $2020: 75-87$ 
81

JURNAL ILMIAH KOMPUTERISASI AKUNTANSI p-ISSN : 1979-116X e-ISSN : 2614-8870 •

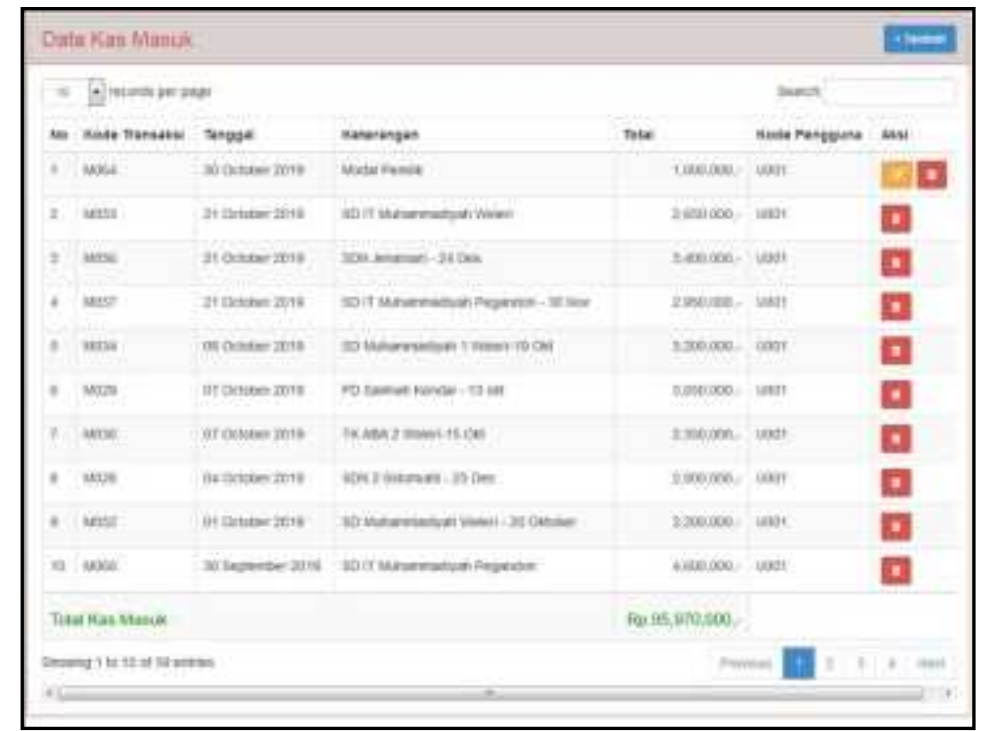

Gambar 8 Halaman Kas Masuk

Sub menu booking digunakan untuk mengelola data booking tiket outbound. Pengguna dapat menambah, mengubah, menghapus data booking tiket outbound dan akan menghasilkan nota booking tiket outbound.

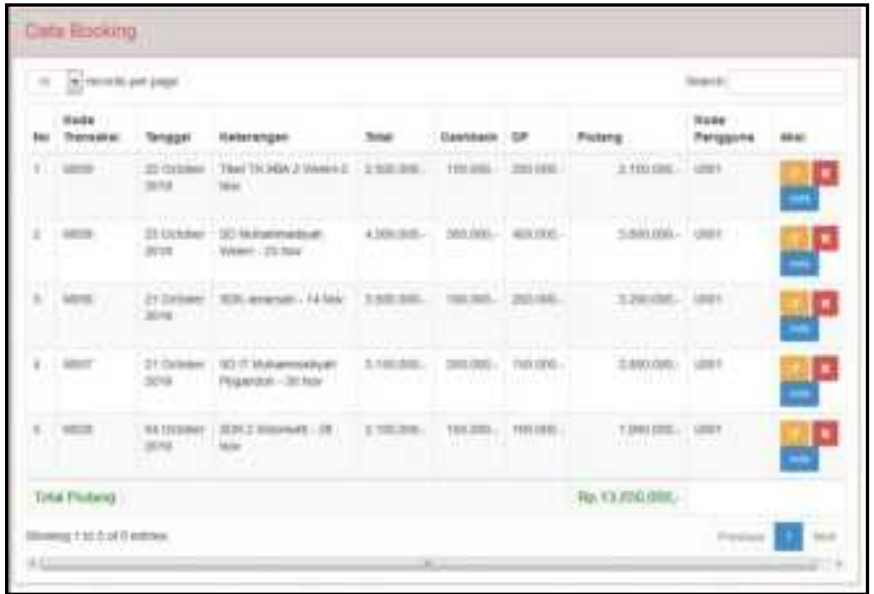

Gambar 9 Halaman Booking

Sub menu pelunasan digunakan untuk mengelola data pelunasan booking tiket outbound dan akan menghasilkan nota pelunasan. 


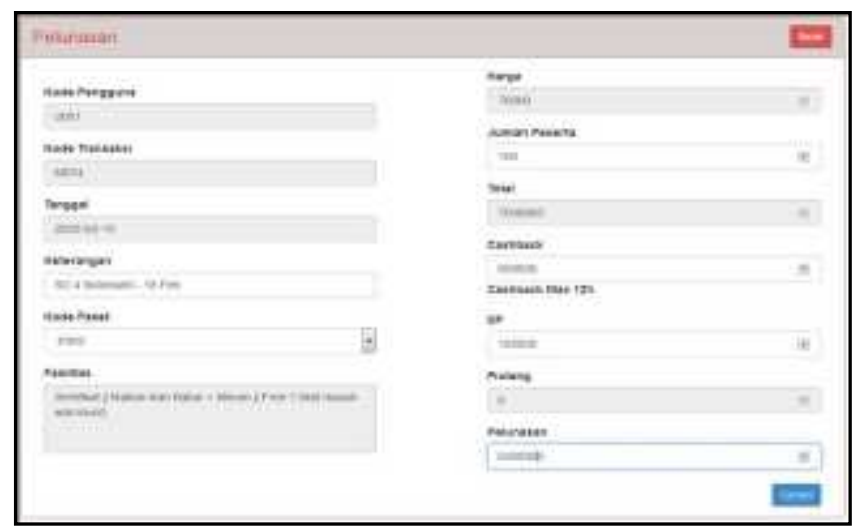

Gambar 10 Halaman Pelunasan

Sub menu kas keluar digunakan untuk mengelola data kas keluar. Pengguna dapat menambah, mengubah, menghapus data kas keluar.

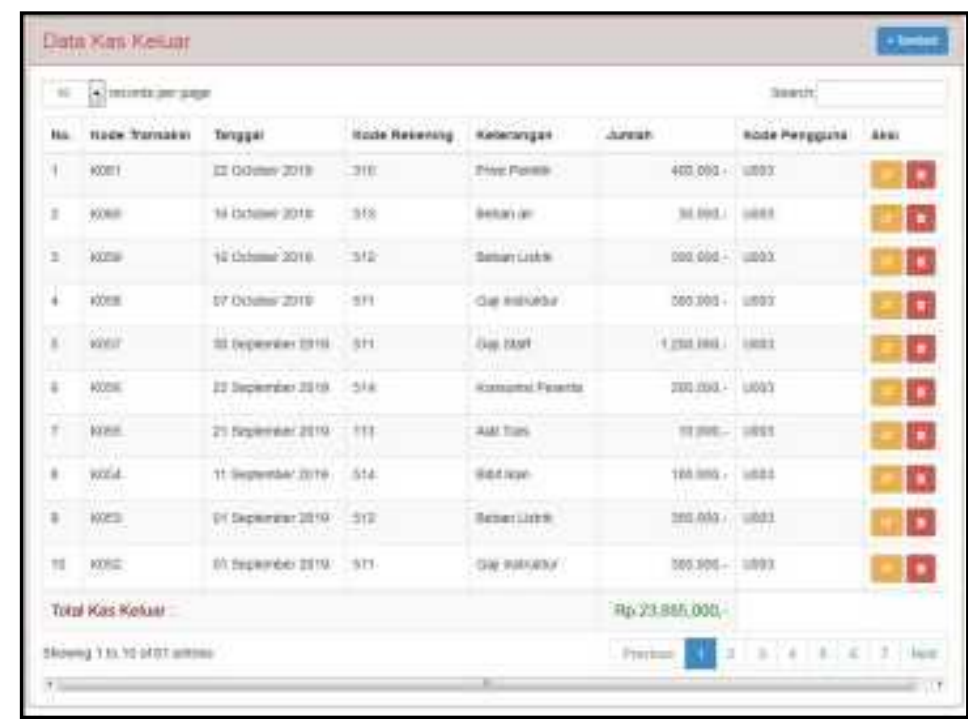

Gambar 11 Halaman Kas Keluar

Sub menu laporan piutang digunakan untuk menampilkan laporan piutang secara keseluruhan atau periode tanggal.

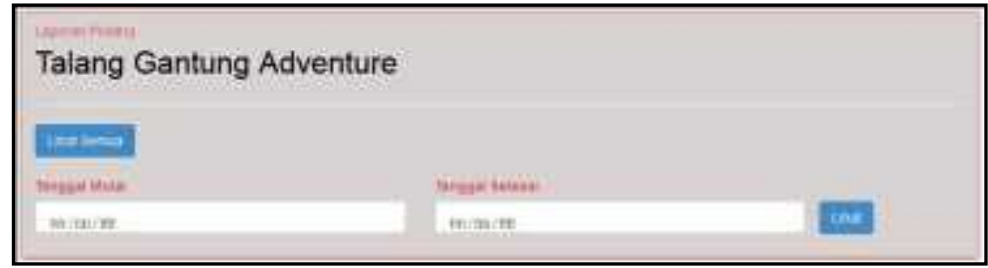

Gambar 12 Halaman Laporan Piutang

JURNAL ILMIAH KOMPUTERISASI AKUNTANSI Vol. 13, No. 1, Juli $2020: 75-87$ 


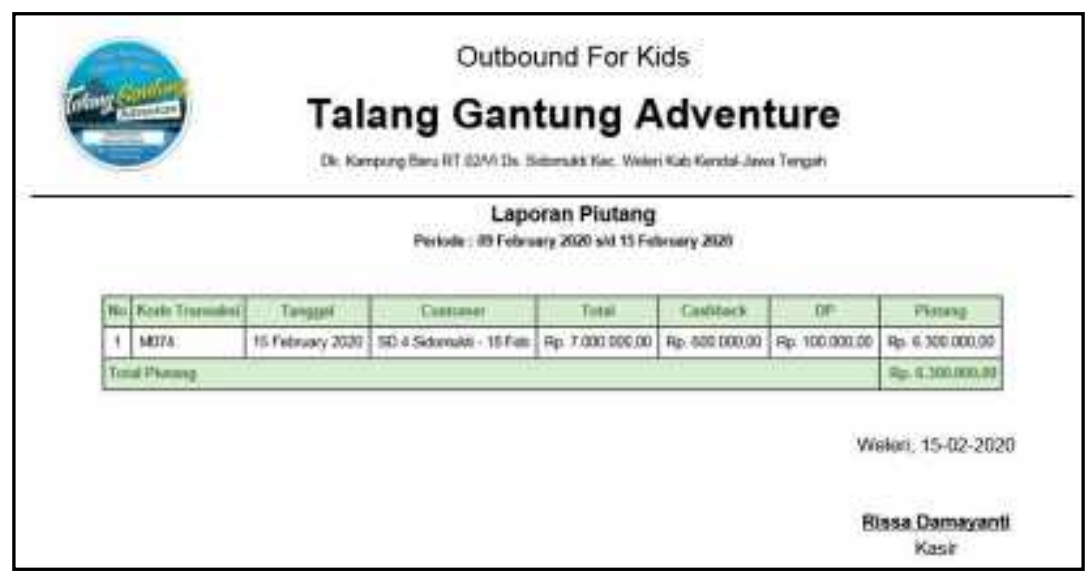

Gambar 13 Tampilan Laporan Piutang

Sub menu laporan pelunasan digunakan untuk menampilkan laporan pelunasan secara keseluruhan atau periode tanggal.

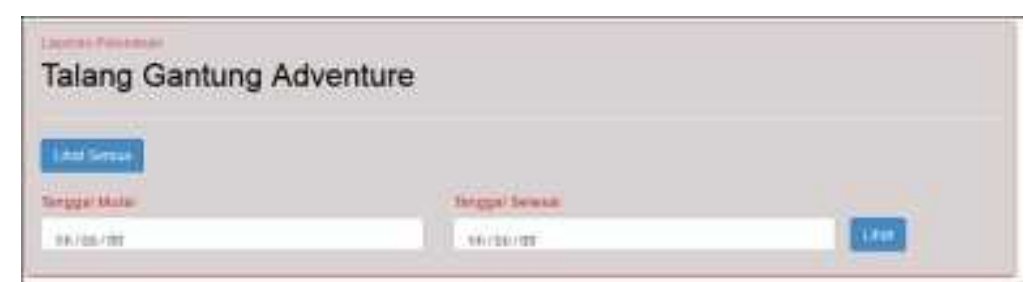

Gambar 14 Halaman Laporan Pelunasan

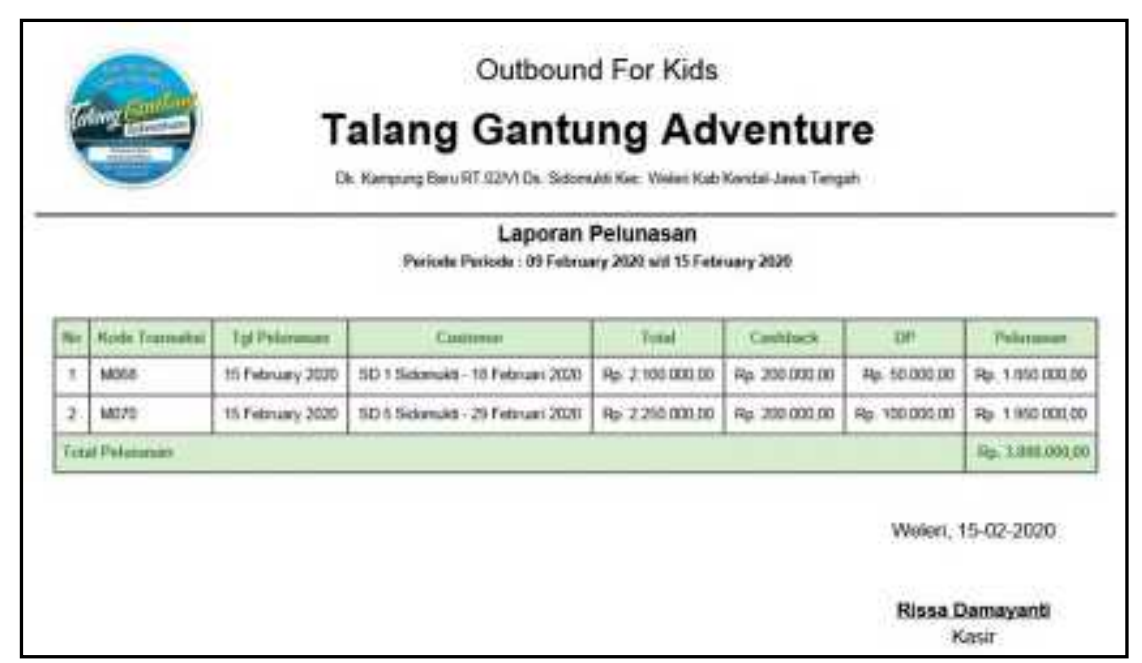

Gambar 15 Tampilan Laporan Pelunasan 
84

Sub menu laporan kas masuk digunakan untuk menampilkan laporan kas masuk secara keseluruhan atau periode tanggal.

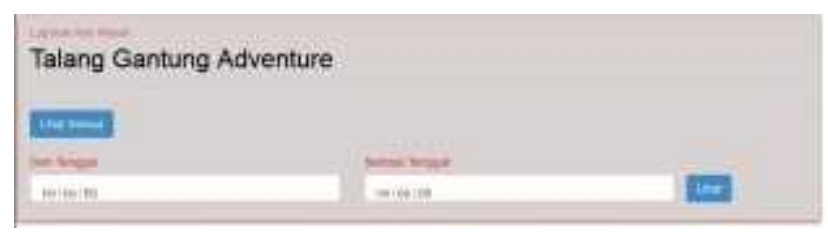

Gambar 16 Halaman Laporan Kas Masuk

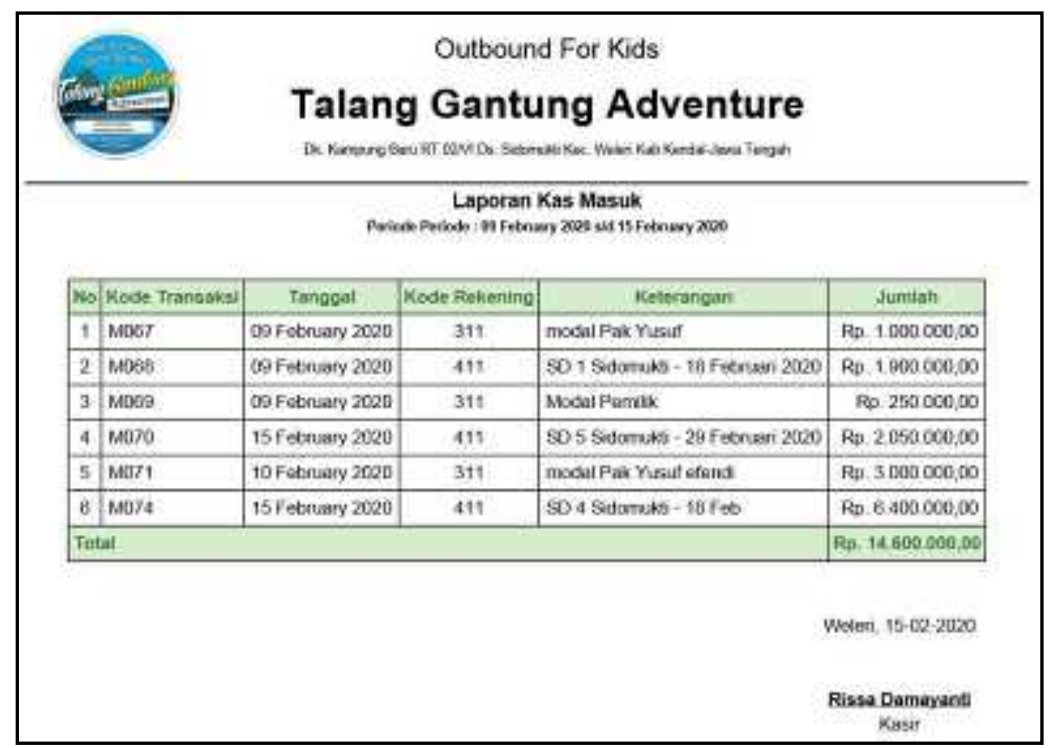

Gambar 17 Tampilan Laporan Kas Masuk

Sub menu laporan kas keluar digunakan untuk menampilkan laporan kas keluar secara keseluruhan atau periode tanggal.

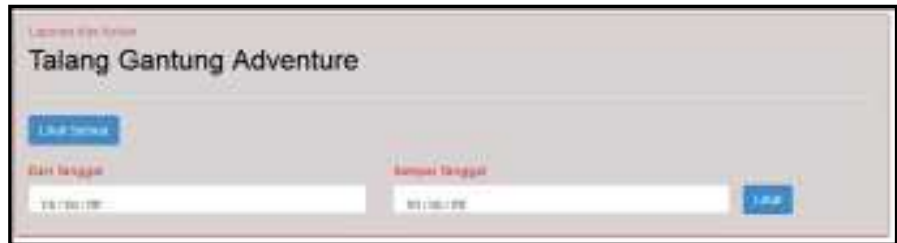

Gambar 18 Halaman Laporan Kas Keluar 


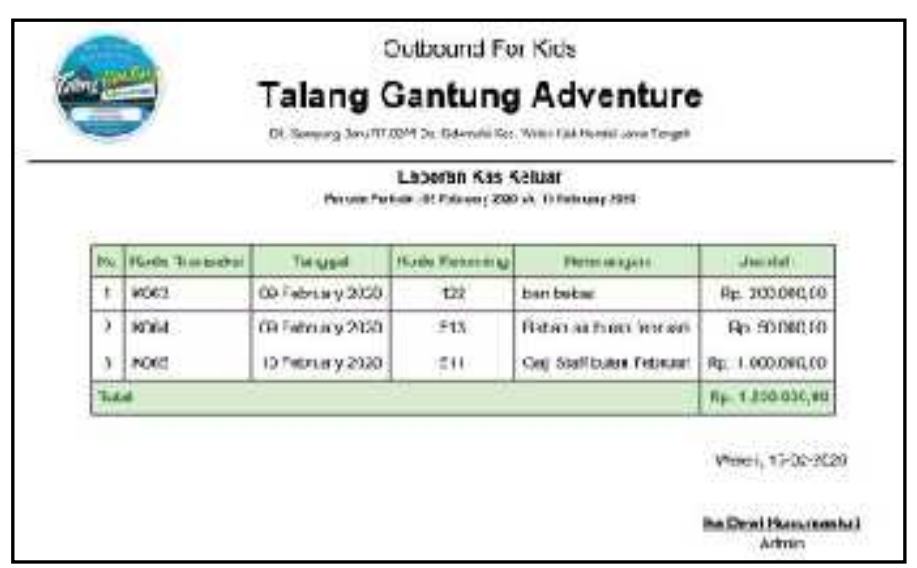

Gambar 19 Tampilan Laporan Kas Keluar

Sub menu laporan arus kas digunakan untuk menampilkan laporan arus kas periode bulan atau periode akhir tahun.

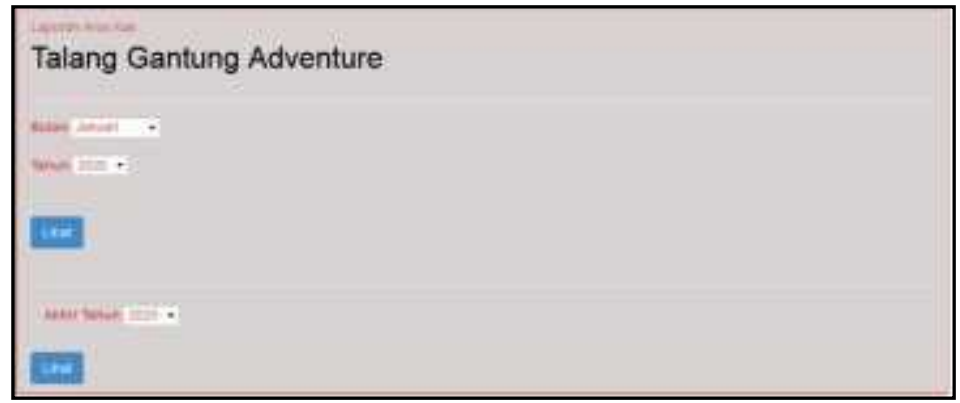

Gambar 20 Halaman Laporan Arus Kas

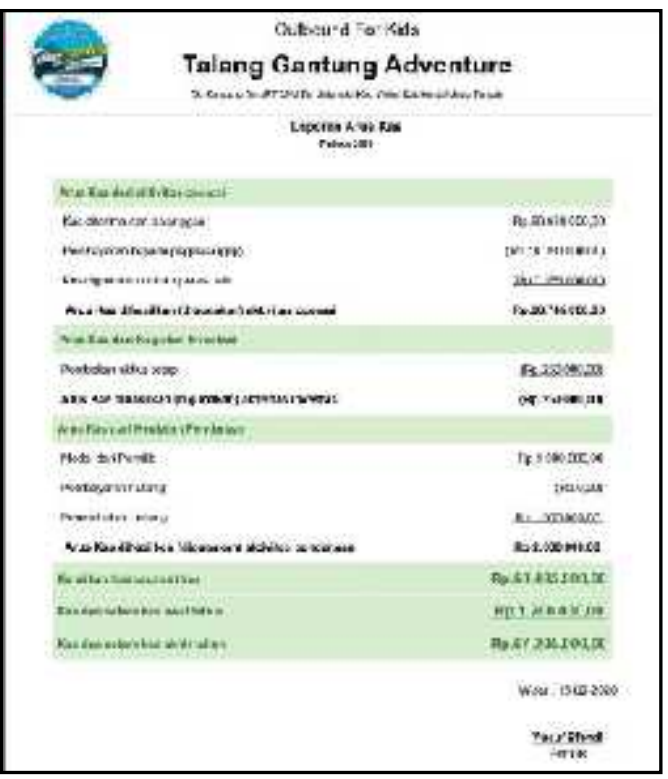

APLIKASI WEBSITE SISTEM INFORMASI AKUNTANSI MANAJEMEN KEUANGAN TALANG GANTUNG ADVENTURE 
Gambar 21 Tampilan Laporan Arus Kas

Sub menu laporan laba rugi digunakan untuk menampilkan laporan laba rugi periode bulan atau periode akhir tahun.

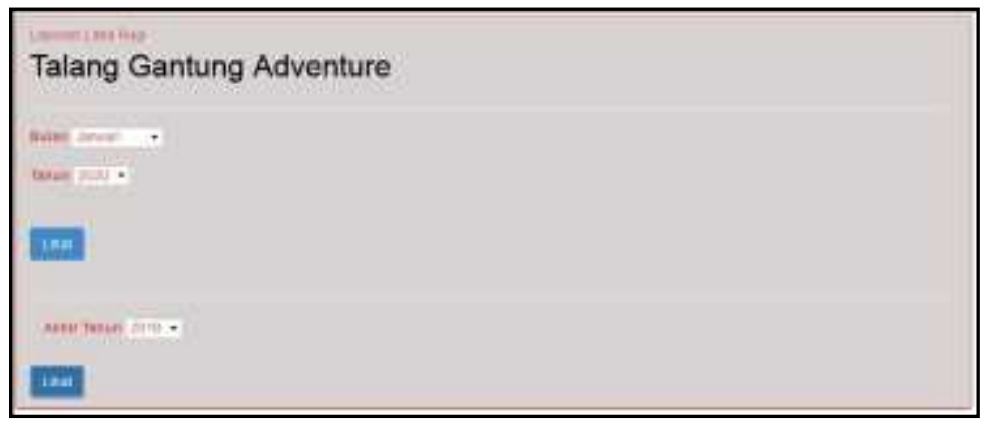

Gambar 22 Halaman Laporan Laba Rugi

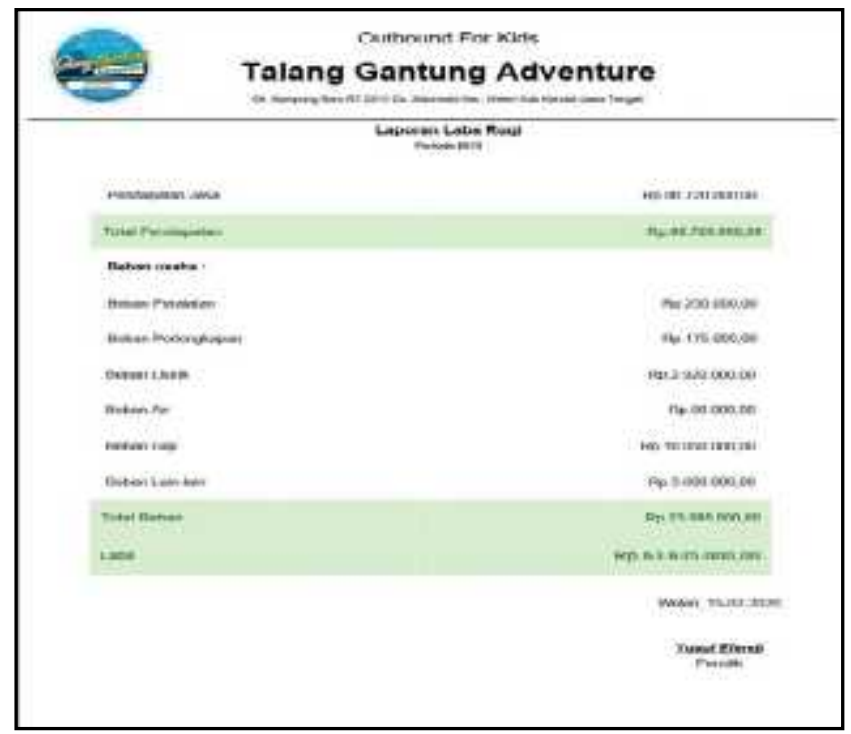

Gambar 23 Tampilan Laporan Laba Rugi

Sub menu laporan pajak digunakan untuk menampilkan laporan pajak periode tahun.

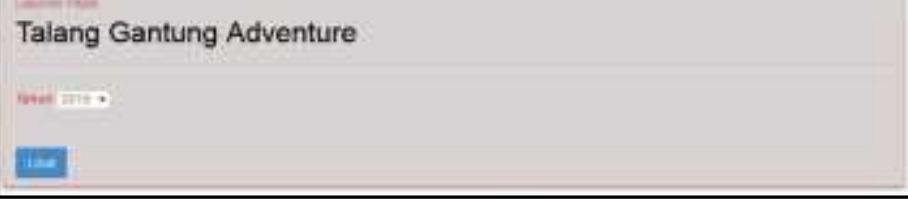

Gambar 24 Halaman Laporan Pajak

JURNAL ILMIAH KOMPUTERISASI AKUNTANSI Vol. 13, No. 1, Juli $2020: 75-87$ 


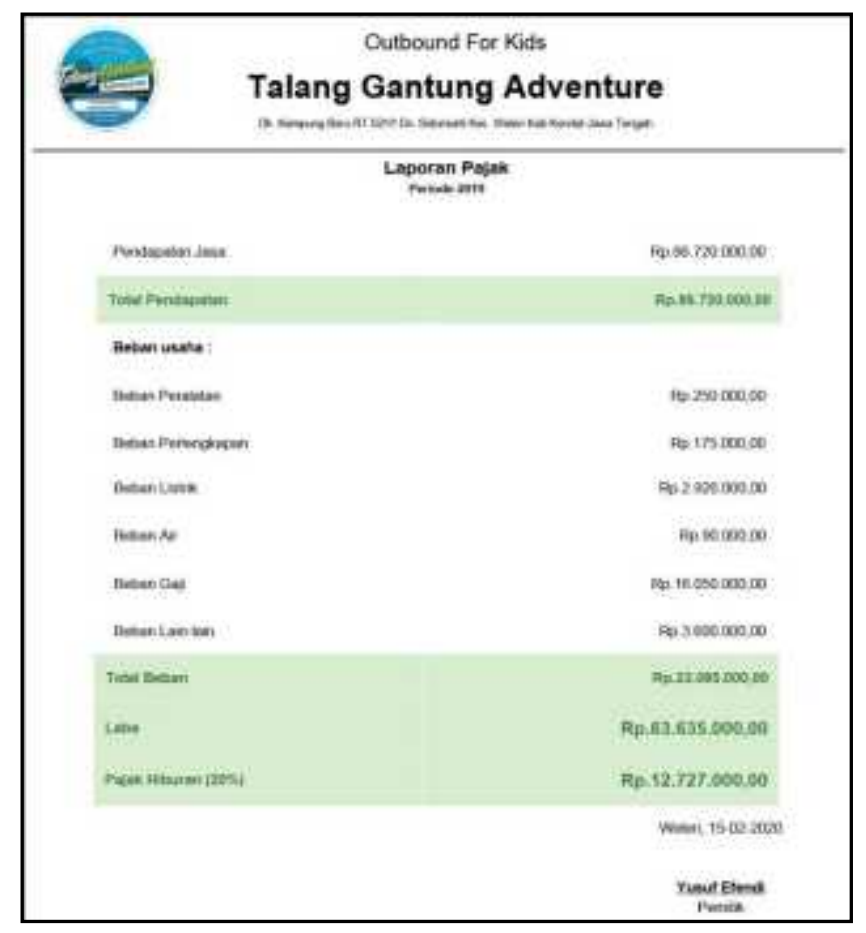

Gambar 25 Tampilan Laporan Pajak

\section{Simpulan}

Peneliti dapat menyimpulkan hasil penelitian tentang aplikasi website sistem informasi akuntansi manajemen keuangan Talang Gantung Adventure telah mencapai tujuan yang diinginkan, yaitu untuk mempermudah manajemen transaksi keuangan yang mampu menghasilkan laporan keuangan yang mudah dilaporkan ke pemilik Talang Gantung Adventure dimanapun dan kapanpun.

\section{Daftar Pustaka :}

[1] Sujarweni, V. W. (2015). Sistem Akuntansi. Yogyakarta: Pustaka Baru Press.

[2] Mulyani, S., \& dkk. (2018). Sistem Informasi Akuntansi : Aplikasi Di Sektor Publik.

[3] Mahatmyo, A. (2014). Sistem Informasi Akuntansi. Yogyakarta: Deepublish.

[4] Musthafa (2017). Manajemen Keuangan. Yogyakarta: CV. Andi Offset.

[5] Fauziah, I. (2017). Buku Dasar-Dasar Akuntansi Untuk Orang Awam dan Pemula. Pamulang: Bumi Pamulang-Bambu Apus.Bandung: Unpad.

[6] Sugiyono. (2016). Metode Penelitian Kuantitatif Kualitatif dan R\&D. Bandung: Alfabeta. 